Cinémas

Revue d'études cinématographiques

Journal of Film Studies

\title{
Loving a Disappearing Image
}

\section{Laura U. Marks}

Volume 8, numéro 1-2, automne 1997

Cinéma et mélancolie

URI : https://id.erudit.org/iderudit/024744ar

DOI : https://doi.org/10.7202/024744ar

Aller au sommaire du numéro

Éditeur(s)

Cinémas

ISSN

1181-6945 (imprimé)

1705-6500 (numérique)

Découvrir la revue

Citer cet article

Marks, L. U. (1997). Loving a Disappearing Image. Cinémas, 8(1-2), 93-111. https://doi.org/10.7202/024744ar

\section{Résumé de l'article}

L'auteure explore comment un spectateur, lorsqu'il est confronté à un film ou à un vidéo détérioré et vieilli, identifie le cinéma comme un média en train de mourir au moment même où il l'observe. Elle parle de plusieurs films expérimentaux et vidéos dont le sujet est la désintégration du film, souvent le film erotique. Un modèle psychanalytique de la mélancolie est avancé pour expliquer ce processus identificatoire, mais il est considéré insatisfaisant puisqu'il fait déjà partie du principe de maintien de la cohérence de l'ego. Un modèle de mélancolie de dévotion est plutôt avancé, afin de montrer comment on pourrait aimer une image en disparition. 


\title{
Loving a Disappearing Image
}

\section{Laura U. Marks}

\begin{abstract}
RÉSUMÉ
L'auteure explore comment un spectateur, lorsqu'il est confronté à un film ou à un vidéo détérioré et vieilli, identifie le cinéma comme un média en train de mourir au moment même où il l'observe. Elle parle de plusieurs films expérimentaux et vidéos dont le sujet est la désintégration du film, souvent le film érotique. Un modèle psychanalytique de la mélancolie est avancé pour expliquer ce processus identificatoire, mais il est considéré insatisfaisant puisqu'il fait déjà partie du principe de maintien de la cohérence de l'ego. Un modèle de mélancolie de dévotion est plutôt avancé, afin de montrer comment on pourrait aimer une image en disparition.
\end{abstract}

\section{ABSTRACT}

The author explores how a viewer identifies with a decaying or disintegrating film or videotape, given that cinema is, in effect, dying even as we watch it. She discusses several experimental films and videos that take as their subject the disintegration of film, often erotic film. A psychoanalytic model of melancholia is posited for this identificatory process, but it is found to be unsatisfactory since it is premised on the maintenance of the ego's coherence. Instead a model of devotional melancholia is posited for how one might love a disappearing image.

Many recent experimental films and videos, flouting the maximization of the visible that usually characterizes their media, are presenting a diminished visibility: their images are, quite 
simply, hard to see. In some cases this diminished visibility is a reflection upon the deterioration that occurs when film and videotape age. Interestingly, a number of these same works also deal with the loss of coherence of the human body, as with AIDS and other diseases. The following essay continues my research into haptic, or tactile, visuality, here to ask what are the consequences for dying images and images of death, when the locus of identification and subjectivity is shifted from the human figure to an image dispersed across the surface of the screen.

In defining a look tied to new ways of experiencing death, these works appeal to a form of subjectivity that is dispersed in terms of ego/identity and yet embodied physically. What this look enacts is something like a perpetual mourning, something like melancholia in its refusal to have done with death. Ultimately, it cannot be described by these Freudian terms. These images appeal to a look that does not recoil from death but acknowledges death as part of our being. Faded films, decaying videotapes, projected videos that flaunt their tenuous connection to the reality they index, all appeal to a look of love and loss.

There are many ways that the visual coherence and plenitude of the image can be denied to the viewer. Among these are the ways films and tapes physically break down, so that to watch a film or video is to witness its slow death. Another is the way significance relies not upon the viewer's ability to identify signs, but in a dispersion of the viewer's look across the surface of the image. The works I will discuss reconfigure identification so that it is not with a coherent subject but with non-human or inanimate objects, and with the body of the image itself. They compel identification with a process, which is material but nonhuman. Amplifying their melancholy quality of the works I have chosen to discuss, many of their archival images are erotic. These works are Frank's Cock (1994) and Letters from Home (1996) by Mike Hoolboom; The Hundred Videos (1992-96) and Everybody Loves Nothing (1997) by Steve Reinke; De Profundis (1996) by Lawrence Brose; The Color of Love (1994) by Peggy Ahwesh ; XCXHXEXRXRXIXEXSX, a performance by Ken Ja- 
cobs, based on a film recovered in 1980 ; and the images in Tom Waugh's 1996 book, Hard to Imagine.

\section{Cinema's dying body}

I began this research contemplating the conundrum of having a body that is not one's own, a betraying, disintegrating body. A body that slowly or quickly becomes other, at least insofar as one's identity is premised on wholeness. This happens with all of us as we age, and it happens acceleratedly for people who have AIDS or other diseases that invade and redefine their bodies. In Letters from Home, Mike Hoolboom expresses the paradox of having a body that is yours but not, when a character relates a dream that he was taken to a room where a handful of crystals was spilled on a table, each of which, he realized, represented an aspect of his personality. "There was my love of the screwdriver and the universal wrench; the break with my sister; my weakness for men in hairpieces." The man displaying these crystals to him becomes a doctor and tells him he is HIVpositive. "And sure enough, he pointed to an off-color stone that was slowly wearing down everything around it."

To have an aging body, as we all do, raises the question of why we are compelled to identify with images of wholeness, as classical film theory would have it; the question of whether this still is or need be the case; and the question of what it would be like to identify with an image that is disintegrating. Following Vivian Sobchack (1992), I suggest that identification is a bodily relationship with the screen; thus when we witness a disappearing image we may respond with a sense of our own disappearance. Cinema disappears as we watch, and indeed as we do not watch, slowly deteriorating in its cans and demagnetizing in its cases. ' Film and video, due to their physical nature, disintegrate in front of our eyes: a condition that archivists and teachers are in a special position to mourn. When I open the can of a color film that has not been viewed in 20 years, the thrill of rediscovering these patiently waiting images is tempered by their sad condition, once-differentiated hues now a uniformly muddy pinkish brown. When I watch an analog tape from the early days of video experimentation, the image appears to have lifted 
off in strips. The less important the film or tape (and by extension, its potential audience) was considered, the less likely that it will have been archived with care, and thus the more likely it is that the rediscovery of the object will be such a bittersweet pleasure. These expected and unexpected disasters remind us that our mechanically reproduced media are indeed unique.

When I began to teach film studies I realized that the students will never "really see" a film in class: it's always a film that's half-disappeared, or a projected video that just teases us, with its stripes of pastel color, that there might be an image in there somewhere, that there once was an indexical relationship to real things, real bodies. One response to this situation can be to see the actual, physical film or video we see as a mnemonic for the ideal film, the Platonic film, once seen in $35 \mathrm{~mm}$ in a good theater. This seems to be Seth Feldman's (1996) argument in "What Was Cinema?," in which he suggests melancholically that the institution of "cinema" has ceased to exist, given that most film viewing experiences occur through the medium of video, at home or projected, and will increasingly take place through digital media. ${ }^{2}$ A notion of the ideal film, which our viewing experiences can only approximate, is also the basis of Paolo Cherchi Usai's (1988) thoughtful argument that cinema history itself would not be possible without the disappearance of its object.

L'histoire du cinéma naît d'une absence. Si toutes les images en mouvement étaient présentes en leur état initial, il n'y aurait pas d'histoire du cinéma, celle-ci ne peut qu'expliquer pourquoi ces images ont disparu, et leur valeur hypothétique dans la mémoire culturelle d'une époque; c'est leur type de disparition qui induit une périodisation. (p. 230)

Cherchi Usai suggests that images take on history as a function of loss: if not of their physical materiality, then of their initial conditions of viewing. Cinema history, then, is a melancholic act from the start, for even in the presence of the fullness of the image one is aware that it is disappearing before our eyes. The cinematic object is gradually transformed from what the image represents to the complex of histories of its destruction. 
The goal of cinema history is to account for its disappearance and its transformation into another object. (Cherchi Usai, p. 235)

A response to the partial and decayed images that pass themselves off for La Règle du jeu or an early Ant Farm experiment on our classroom screens can be to accept that "this" film or tape is the one we have, and to deal with its own peculiarities, the way it lays a map of the indignities it has suffered over the represented image. Disappearance restores aura to the work. Mechanically reproduced images supposedly lack aura, but as images decay they become unique again : an unhappy film is unhappy after its own fashion. The scratches and unintentional jump cuts on our print of $\mathrm{X}$ film are ours alone, and even video decays individually, in response to temperature, humidity, and the idiosyncrasies of playback machines. Of course, independent, experimental, and rare films and videos are already auratic, as anyone knows who has tried to replace their lost home movies or their vanished copy of Koko the Clown. Works that are not widely distributed are more like bodies that we protect assiduously than like simulacra.

I have been discussing the accidental aura of films that decay and disappear due to mechanical reproduction and physical wear and tear. Many film and videomakers intentionally work this process of dissolution into their productions, incorporating the halo-like colors of deteriorating nitrate, the blurring of multigenerational analog images, or the cruel lines of static on erased video. A few recent examples include: Peter Delpeut's Lyrical Nitrate (1990), a love letter to the disappearing images in nitrate movies; Barbara Hammer's Nitrate Kisses (1992) which searches eroding footage for traces of lesbian and gay histories; Atom Egoyan's films, many of which play with erased or barelyvisible video as an analogue for memory; and many art videos that use the decay of the image to refer to memory loss. All these works borrow the aura of the disappearing images upon which they meditate. A very poignant example is Ming-Yuen $S$. Ma's short video Sniff (1996), where a man crawls on his bed, inhaling for the smell trace of his departed lovers - perhaps gone forever. " $\mathrm{M}$ came over last night. He had two scoops of ice 
cream, and some chocolate." As the abandoned man moves with increasing desperation, the image breaks down, losing its identity the way smell particles disperse, taking memory away with them.

To love a disappearing image one must trust that the image is real in the first place; that is, that it establishes an indexical link between the long-ago and objects recorded by a camera and the present-day spectator. We mourn the passing of the young lovers/actors because we are sure that they existed: the photograph is a sort of umbilical cord between the thing photographed "then" and our gaze "now." (Barthes, 1981, p. 127) The real mourning occurs when that umbilical cord is severed. Film historian Tom Waugh encountered insurmountable problems when he attempted to reproduce archival gay pornography in his book Hard To Imagine (1996). ${ }^{3}$ After the manuscript went through the hands of several editors who refused to publish the explicit images, Columbia University Press finally agreed - on the condition that, in addition to the removal of some images, the faces in nine of the old photographs be altered to avoid potential lawsuits. Bitterly, Waugh describes how he had to hire a computer "whiz kid" to digitally graft new faces onto the archival porn images, and the travesties that resulted. What was lovable about these old pornographic images was their indexical witness of particular individuals, which is destroyed by alteration. In effect, perceiving the images to be insufficiently dead, Waugh's lawyers devised a way to murder them.

\section{Disappearance and identification}

How does one identify with dying images? Recall that cinematic identification was first defined by Metz (1992) as identification with a character (secondary), or with the look of the apparatus itself (primary); more recently, secondary identification came to be redefined as an oscillation among many subject positions. Secondary identification remains understood as identification with a person, or a personified being. In contrast, I suggest that secondary identification may be with an inanimate thing or things; and that primary identification itself may be an identification with dispersion, with loss of unified selfhood. ${ }^{4}$ 
I believe I gained this view of primary identification by attending many screenings in artist-run centers, ill-heated, with projectors rented from the public library. In these circumstances identification with the apparatus is decidedly "not" a position of power. The miserable viewing conditions at many institutes of higher learning also instill this weakened identificatory position.

Primary identification can be an identification across differences, as we have come to understand secondary identification to be. As such it need not attempt to make good the viewer's partial position; instead it invites the viewer to "take part" in a dispersed subjectivity. Identifying with dispersion might seem to resemble the self-destructive process of heteropathic identification; that is, identifying with one who is different even though it may threaten the self. (Silverman, p. 23-24) However, where my position fundamentally diverges from the Lacanian psychoanalytic basis of heteropathic identification is that I question whether identification with difference necessarily annihilates the self. Lacanian psychoanalysis posits that identity is built on the dread of alterity. I assert, however, that the confrontation with the other does not necessarily destroy the self.

Frank's Cock by Mike Hoolboom is one work that invites the viewer to relate to an image precisely in its dissolution. The film does this both by having a structure in which each part loses its separate coherence by being justaposed with the others, and by using images that are themselves hard to see. The screen is divided into four parts: first, in the upper right quadrant, a man comes on (Callum Rennie), telling the story of Frank, his lover, who is dying; then, in the upper left quadrant, shots of wiggling micro-organisms appear (they connote viruses, but to me they also look like the Brownian motion of people moving around in a bar); then, in the lower right, Madonna's Sex video comes on; and in the lower left emerges a grainy dub of gay pornography.

Although the story of Frank's lover commands the space of the film, it shifts from being a confessional AIDS movie where we identify, perhaps condescendingly, with the speaker, to one that divides our attention across four interior movies, each of which disperses the others. Divided this way, the image refuses a 
single narrative that would comprehend the loss. The film also asks us to celebrate fucking, and the mingling of microorganisms, as we listen to the lover's unapologetic tale. It provides a variety of images of sex: the swimming one-celled creatures compete for attention with the choreographed forms of Madonna and her lovers, begging the question, with which do you identify more? Critics celebrated the film because it made the figure of a gay man with AIDS "universal," but I would suggest that this means not simply open to universal identification. Instead (or as well), the film moves beyond identification to an acknowledgement of dispersion.

In Letters from Home, Hoolboom comes out as a person with AIDS, but this concretization is only partial, for his first-person testimony is spoken by many other people. Hoolboom becomes one actor among others speaking the words of a person with AIDS, at the same time that all the people in the film become people with AIDS. I believe this is a more appropriate way to deal with AIDS than the heroic narrative centering on an individual's suffering. "The lack of closure in the "fight against AIDS" becomes a lack of closure for the viewer.

In Letters from Home, not only is the identity of person with AIDS dispersed across many subjects with whom one might identify. Also, meaning is dispersed throughout the film onto a great variety of archival images and sounds: Hoolboom as a boy, wiping his face with his shirt as he walks toward the camera; a 1920 s film of people trying in vain to unstick a car from the mud; the spectacular crash of a biplane from the period, accompanied by Billie Holiday's "You've Changed"... And finally, the look itself becomes dispersed, in the way many of the images themselves break down or lose legibility. The battered, sepia-toned film of a stumbling bride suggests an unrecoverable past time; the face of the last speaker (actor Callum Rennie, reading Mike's words) is half-obscured by a flash of light; the faded clips of old home movies seem to have been watched one too many times.

Old pornographic images are a logical place to look for lost love. Filmmakers Peggy Ahwesh and Ken Jacobs turn their cherishing techniques on these profane images, using optical printing and frame-by-frame projection to draw out their nuances, 
searching for real gestures of intimacy in between the choreographed performances. I have discussed Jacobs's film/performance $X C X H X E X R X R X I X E X S X$ in detail elsewhere (Marks, 1993). Here let me note Jacobs's technique of projecting the reprinted images through an apparatus called the Nervous System one frame at a time, manipulating the projector to create a sense of movement and changing light within each single frame. The film in question is a five-minute hard-core porno from the 1920 s, called Cherries. In Jacobs's projection, the images of two women and a man cavorting and fucking in an orchard are in part rendered abstract, a von Sternburgian play of pattern and light. But the time Jacobs creates for contemplation also allows the viewer to reflect upon this long-ago performance, and to imaginatively create new narratives, sexual or not, from the pornographic set piece. In this Jacobs shifts the viewer's engagement with the images from a prescriptive, "action" mode to a contemplative one.

The Color of Love began when experimental filmmaker Peggy Ahwesh found a Super 8 amateur porn film in the trash. In it two women straddle the disturbingly passive and bloodstained body of a man, tease his flaccid penis with a knife, and then make love to each other in straight-porn "lesbian" style, the camera moving in on their genitals. The film had deteriorated badly, its emulsion bubbling around the remains of the image in garden-party hues of rose, turquoise and green. Ahwesh tenderly exploited the effects of this deterioration, slowing and stopping the film at points and accompanying it with a lugubrious tango. In slow motion we may watch as one of the women lifts her head in real or simulated pleasure while the other woman kisses her breasts, while the deteriorated emulsion curtains and reveals them. Given the mechanical quality of the performance, the man's flaccid penis, and the disengorged labia of the women, it seems that the real erotic activity in The Color of Love is in the game with death taking place on the surface of the film. Choreographed by the tango, the film's emulsion flowers and evaporates, giving itself up to bliss and to death.

Lawrence Brose, like Hoolboom and Ahwesh, has for years used experimental styles to eke out what is precious in the 
image. His recent work, De Profundis (1997), uses Oscar Wilde's aphorisms and his searing letter from prison, emphatically performed by Agnes de Garron, as a basis to explore the figure of the homosexual outlaw. These texts are laid over a vast array of imagery, including vintage gay pornography and contemporary Radical Faerie gatherings. Step-printed, the archival porn films are presented a couple of frames at a time, so that a contemporary viewer can contemplate the gestures and expressions of, for example, a man in a sailor cap who teasingly lowers his pants and then, grinning, pulls them up again as he walks toward the camera. A man swimming naked in one recurring image appears, when printed in negative, to be running in quicksand a counterpart to the despair of Wilde's letter to the lover who betrayed him. Brose's hand and chemical processing mimics and exploits the effects of the vintage films' deterioration, and like Ahwesh's film the result is sublime. Explosive colors and texture glorify the long-ago illicit love scenes, with a defiance that matches Wilde's words. Indeed Wilde's advocacy of perversion as an ethics and an aesthetics seems to influence the film's ethos of contamination: figures bleed into the surface patina as a final voice-over whispers, "It is so easy to convert others - that is why they find us dangerous." De Profundis is about coming through unbearable anguish and surviving, and the gloriously wounded images metaphorize Wilde's descent into and return from despair: "While for the first year of my imprisonment I did nothing else... but wring my hands in despair and say, 'What an ending - what an appalling ending.' Now I try to say to myself, and sometimes, when I am not torturing myself, do really say, "What a beginning — what a marvelous beginning.'

\section{Melancholia}

In revaluing melancholia, I would like to argue that the mourning subject need not rediscover his/her coherence at the cost of ceasing to love the lost loved one, as Freud describes "successful" mourning. Rather, I suggest, mourning can involve the "loss" of self and its reconfiguration and redistribution. Freud wrote in "Mourning and Melancholia," 
Each single one of the memories and situations of expectancy which demonstrate the libido's attachment to the lost object is met by the verdict of reality that the object no longer exists; and the ego, confronted as it were with the question whether it shall share this fate, is persuaded by the sum of the narcissistic satisfactions it derives from being alive to sever its attachment to the object that has been abolished. (p. 255)

With some ruefulness, Freud argued that this process of separation from the loved one, indeed killing the loved one again in memory, was necessary for the survival of the ego. The alternative to mourning, according to Freud, is melancholia, in which the subject never gives up its investment in the lost loved one, and thus becomes incapable of transferring its love to a new object. Unlike mourning, in melancholia the lost object is hidden from consciousness: "[...] even if the patient is aware of the loss which has given rise to his melancholia, but only in the sense that he knows 'whom' he has lost but not 'what' he has lost in him." (p. 245) Perhaps this describes the melancholia that one feels when viewing an image of an unknown person. We cannot know who this person was, but we mourn his or her passing and feel a generalized sense of loss in the wake of history's rough treatment of the forgettable.

As William James noted the melancholic diminution of the ego comes close to being an acknowledgement of the actual human condition, against which a healthier person has ample defenses. James wrote that melancholia has a quality of realism, for if one conceives of the world "as it is, purely in itself," stripped of one's emotional investment, "it will be almost impossible... to realize such a condition of negativity and deadness." (p. 147) James quotes Tolstoy: "One can live only so long as one is intoxicated, drunk with life; but when one grows sober one cannot fail to see that it is all a stupid cheat." (p. 151) Lacanian theorists, of course, amply support the theory that the ego is a sturdy bulwark against our fundamental self-less-ness. ${ }^{6}$

Roland Barthes's meditation on the "Winter Garden" photograph of his mother in Camera Lucida suggested that photography itself is a melancholic medium. "Nothing in [the photo- 
graph] can transform grief into mourning." (p. 90) Photography, he suggests, blocks the act of memory. It fixes the past and substitutes the signs of the image for the creative engagement of memory. To view a photograph of a lost loved one, then, is a melancholic act in which the viewer "knows 'whom' he has lost but not 'what' he has lost in him." (Freud, p. 245)

Je ne puis transformer la photo qu'en déchet: ou le tiroir ou la corbeille. Non seulement elle a communément le sort du papier (périssable), mais, même si elle est fixée sur des supports plus durs, elle n'en est pas moins mortelle: comme un organisme vivant, elle naît à même les grains d'argent qui germent, elle s'épanouit un moment, puis vieillit. Attaquée par la lumière, l'humidité, elle pâlit, s'exténue, disparât ; il n'y a plus qu'à la jeter. (Barthes, 1980, p. 145-146)

Barthes finds that the mortality of his photographs, their blurriness, fading, and decay, render them unbearably abject. When not only the "what" being mourned but the "whom" becomes illegible, the photograph must be rejected, lest its mortality contaminate the life of the viewer. In what seems an understandable and "healthy" conclusion to mourning, Barthes throws the old photograph away. ${ }^{7}$

Yet I would like to suggest that the very blurriness and illegibility of the photograph that Barthes finds abject may "aid" the process of memory. As I discuss elsewhere (Marks, 1996 and 1998), an image that is grainy, indistinct, or dispersed over the surface of the screen invites a haptic look, or a look that uses the eye like an organ of touch. This is how "love" works into this sort of identification. A tactile look does not rely on a separation between looker and object as a more optical or cognitive look does. Such touch-like vision is not conceived of as an assault (either an idiopatic assault upon the other, or a heteropathic assault upon the self), so much as a closing of the distance between viewer and image. Because it does not rely on the recognition of figures, haptic looking permits identification with (among other things) loss, in the decay and partialness of the image. This sort of look, then, is not just about death, but about loving a living but non-coherent subject, an image that contains 
the memory of a more complete self. This look is a kind of reverse mirror stage: we identify not ("jubilantly") with a self that is more unified than we are, but with a self that is aging and disappearing. Perhaps a fading photograph of one's own lost loved ones is too violent to contemplate: the image that robbed one of memory itself being drained of life. But I do believe the melancholia evoked by a dying image may produce not dread but a loving regard.

Many of Steve Reinke's short works included in The Hundred Videos (1992-96) are devoted to found footage of anonymous or fictional boys and young men, on whom the artist lavishes the perverse affection of a habitual seducer. In "Artifact," clips of a 1970s CBC documentary called The Children of Sri Lanka are re-presented in "the edited version that desire has consigned to my memory." Reinke eroticize the brown-skinned boys of the documentary as they ride water buffalo or rebuff the phallic attentions of an elephant's trunk that reaches in window. The handsome young bowling champion of "Corey" is rescued from cable-television oblivion by the videomaker's voiced-over amorous fan letter. But what Reinke returns to most insistently is the damaged young men to whom he would be doctor and lover. "Wish" examines an archive of medical photographs of skin diseases, supposedly from the collection of a Philadelphia doctor in the 1930s. Each photograph is fetishistically divided into parts which are matted into the black screen : the rosaceous ears of one young sufferer, the skin rash covering the chest of another. "Be my leper," the artist pleads in voice-over; "Be my love." These diseased skins attract the artist's sympathy in the same way that decaying images do in other tapes: they are signs of passing beauty that must be revived in the memory of the viewer, for the people and images themselves are now dust.

In Everybody Loves Nothing Reinke again turns his possessive gaze to various kind of found footage: medical films, home movies, an Air Force training film. Reinke edits these, or pairs them with text or voice-over, to make explicit their sense of mourning a passing. He pays special attention to a 1950 s medical film documenting treatments for hypogonadism in male adolescents. The officious voice-over of the found film narrates 
one chubby, effeminate boy's emergence into "a normal man" thanks to testosterone injections: new body hair, deeper voice, increased musculature, and enlarged genitals. Reinke edits the footage to construct an uncomfortably long close-up of the youth's tiny "before" penis, tucked like a rose in the folds of his flesh. This might seem prurient, except that the original voiceover is so certain in its condemnation of the boy's "abnormal" state that we get a sense that Reinke is on the side of the image against the voice-over. He cherishes the young man in his insufficiently male state, caressing the image of a youth who will disappear into the ranks of the heathily (heterosexually) male. This exchange shares with the other sequences of Everybody Loves Nothing an ardent desire to revive the lost past from a disappearing image. In a later sequence, we see a tourist video of a Punch and Judy-type puppet show, so faded that one can barely decipher its bouncing and grinning, vaguely terrifying figures. Reinke's gentle voice explains, "If I were to offer a synopsis of the play, it would be, 'Do not come for me, Death, for I am just a tourist.' But really, it is probably, 'Do not come for me, Death, for I am just a child.'

\section{Devotional melancholy}

In the accounts of Freud, James, and even Barthes, melancholia is seen as morbid and suspect in that it eats away at the ego. The melancholic cannot love, Freud argues; she (or he) cannot have healthy religious experience, James argues; and her/his condition is exacerbated by the decaying images of the beloved, Barthes adds. Is there any way to imagine an act of perpetual mourning that is at the same time an act of love? The works I discuss here turn their attention to images that were "not" precious but merely efficacious: the porno, the medical film. Loving a disappearing image can be a way of rescuing something that was not loved in its own time.

Freud's understanding of melancholy, and Barthes's as well, seems symptompatic of the Western conviction that the world revolves around the ego. The Freudian definition of love is also tied up with the ego's coherence. Yet if we can imagine a subjective state in which the self manages to exist without investing in the il- 
lusion of its own completeness (a big "if" for Freudian and Lacanian psychoanalytic theory), then we can imagine that mourning might persist without morbidity. We can imagine that melancholy does not preclude love but merely maintains love in the face of knowledge that the object of love is (always being) lost.

Here I would like to call upon another definition of melancholy, which James attributes to the "sick soul" in his Varieties of Religious Experience, but which in other religious traditions is a sort of divine ecstacy. Devotional poetry addresses the deity in the melancholic tone of a lover addressing the unhearing beloved. As one example, consider the Bhakti movement, or way of devotion, begun in South India around the sixth century. I could also mention the writings of Christian mystics, in which the union with and separation from the deity are as passionately anticipated and regretted as earthly meetings and partings with a lover. Bhakti, or "self-less devotion to God" (Sandilya, 1974), would seem to run against the cultivation of a healthy ego. Indeed, as with other Eastern and mystical faiths, its goal is the dissolution of the ego, which is considered an illusion preventing the devotee from becoming one with the infinite.

Where do I go from here?

I can't stand the soft bells, the gentle breeze, the dark water-lily, the darkness that conquers day, the dulcet notes, the jasmines, the refreshing air.

The Lord, my beguiling one, who creates, bores through, swallows, and spews this earth, who measures here and beyond, does not come.

Why should I live? (Tiruvaymoli 9.9.2; quoted in Narayanan, p. 42)

The devotional poets' pleas for divine grace despite the unworthiness of the petitioner (Narayanan, p. 66 and 97-99) are comparable to the self-abnegation of the melancholic. Indeed the abject longing of the mystical lover for the Beloved is its own reward. The Islamic mystical poet Rumi (1207-1273) told of a man who stopped praising Allah when a cynic asked if he'd ever heard anything back: 
He quit praying and fell into a confused sleep.

He dreamend he saw Khidr, the guide of souls,

in a thick, green foliage.

"Why did you stop praising?"

"Because I've never heard anything back."

"This longing

you express 'is' the return message."

The grief you cry out from

draws you toward union. (Rumi, p. 155)

Can this form of religious devotion be a model of the melancholic subjectivity of the mere filmgoer? I suggest it can. In recent years the ego has lost its position of supremacy both in psychoanalytic theory and in film theory (with its emphasis on masochism, fluid identification, etc.), as well as in postmodern theories of the subject. In light of this revision one may review Freud's rueful claim that the ego chooses survival over love. It seems to be easier, in the age of AIDS, to give up a unified subjectivity that we are less convinced we had in the first place. Melancholia, the refusal to discard the dead loved one from our selves, makes sense if our selves are composites anyway. Devotional poetry offers a model of love of the absent beloved in which the ego is, indeed, dispersed. This dispersion is claimed as a joyful reunion with the beloved rather than a fearful annihilation.

Let me push my argument that it is possible to identify with a dispersed subjectivity without dread, by pointing out the current hype of the new protease inhibitor drugs that "cure" AIDS, drugs that supposedly renders AIDS just another chronic disease like diabetes. This media hype clearly reflects a desire to get AIDS off the screen and back into the lives of those "other" people who have it. The rush to celebrate the "cure" is an act to contain AIDS and to separate the infected bodies from the clean ones, to make AIDS a minority issue again. ${ }^{8}$ The works I have discussed, which still love the disappearing bodies to which they are devoted, argue the opposite: that we all have AIDS.

Clearly one appropriate response of mourning is fetishism : in the case of AIDS, the Names Quilt, as Douglas Crimp (1990) points out, the many loving documents and documentaries of individuals who have died: hyper-cathecting and then detaching from the beloved one. In this paper, however, I am suggest- 
ing another response of mourning that is anti-fetishistic: it does not concretize the loss in an object but expresses the loss through the dissolution of objects. If this is melancholia, then I suggest that melancholia can be a subject-dispersing, loving response to loss. Mourning the death of an image is far less traumatic, of course, than mourning a loved one. Yet I argue that engaging with a disappearing image has some results for the formation of subjectivity, or precisely, a subjectivity that acknowledges its own dispersion. This engagement has some results, too, for engaging with people and with death. The response to death in these works is not fear but an embracing: not the morbid embracing of death, but an embracing of the self's relations with others and with all matter, which is, after all, in a state of constant dissolution. ${ }^{\text {? }}$

\section{Carleton University}

\section{NOTES}

1 I include single-channel video in the category of cinema.

2 Feldman suggests that the "assaultive" style of contemporary cinema makes it more oriented toward spectacle, or toward a "cinema of attractions." This is an interesting assertion, because the "attraction" of early cinema was not the attraction of secondary identification with characters in a movie but a relationship with the screen image itself. In this essay I argue that identification with the screen, and with a screen image that is dissolving and incomplete, permits a look that acknowledges death.

3 Waugh describes this process of legal and digital censorship in his essay "The Archaeology of Censorship." in Lorraine Johnson (editor), Suggestive Poses: Artists and Critics Respond to Censorship. Toronto: Toronto Photographer's Workshop and Riverbank Press (1997), and in John Greyson's Uncut (1997), a film about censorship and legal rights to the use of images, among other things.

4 Certainly this has much to do with masochistic identification, as theorized differently by Gaylyn Studlar (In the Realm of Pleasure: Von Sternburg, Dietrich, and the Masochistic Aesthetic. Chicago/Urbana: University of Illinois Press, 1988) and Steven Shaviro (The Cinematic Body. Minneapolis : University of Minnesota Press, 1994); although, as my essay suggests, even the position of masochism presupposes a particular organization of the subject around the ego which is not necessarily the case.

5 As Kobena Mercer ("Recoding Narratives of Race and Nation," Welcome to the Jungle: New Positions in Black Cultural Studies. New York/London : Routledge, 1994, p. 69-95), and before him Third Cinema theorists such as Fernando Solanas and Octavio Gettino ("Towards a Third Cinema," in Michael Chanan (editor), Twenty-Five Years of New Latin American Cinema. London: British Film Institure, 1983), argue, narrative closure is often inappropriate in films made within minority communities, because the struggle will still be going on when the film is over. 
6 Kaja Silverman's The Threshold of the Visible World (New York/London: Routledge, 1996) is a polemic against the damage our sturdy egos do to our ability to love. I had initially considered it a possible model of the melancholic love I attempt to describe in this essay. However, in Silverman's framing the ego must be brought kicking and screaming to the operation table, whereas I suggest this violent approach is symptomatic of an ethnocentric and somewhat outdated theory of ego.

7 Timothy Murray offers an interesting discussion of Barthes's photographic melancholia (Like a Film: Ideological Fantasy on Screen, Camera and Canvas. London/New York: Routledge, 1993, p. 86-89).

8 The practice of safe sex certainly is a pointed example of the cultural desire to preserve individual boundaries : never getting to taste one's lover and touch one's lover on the inside, because of fear of contracting HIV. Douglas Crimp argues for the need to "have promiscuity in an epidemic," in order not to capitulate to social directives for gay men (and others) to "clean up" and embrace a life of monogamous, "committed," and circumscribed sexual encounters, that would mimic the heterosexual norm.

9 Warmest thanks to Shauna Beharry for her support and suggestions during this writing.

\section{WORKS CITED}

Barthes, Roland. La Chambre claire. Paris: Gallimard/Seuil/Cahiers du cinéma, 1980. Crimp, Douglas. "Mourning and Militancy," in Russell Ferguson, Martha Gever, Irinh T: Minh-ha, and Cornel West (editors), Out There: Marginalization and Contemporary Culture. New York: New Museum of Contemporary Art (1990), p. 233245.

Feldman, Seth. "What Was Cinema?" Canadian Journal of Film Studies, vol. 5, n" 1 (1996), p. 1-22.

Freud, Sigmund. "Mourning and Melancholia," The Standard Edition of the Collected Psychological Works, vol. XIV (1957), p. 243-258.

James, William. "The Sick Soul," The Varieties of Religious Experience. Cambridge: Harvard University Press (1985), p. 125-162.

Marks, Laura U. "Here's Gazing at You." The Independent, vol. 16, n" 2 (1993), p. 26-31.

Marks, Laura U. "The Haptic Critic." Framework, vol. 8, n"1 (1996), p. 18-21.

Marks, Laura U. The Skin of the Film Intercultural Cinema, Embodiment, and the Senses. Durham: Duke University Press, 1998 (forthcoming).

Mercer, Kobena. "Recoding Narratives of Race and Nation," Welcome to the Jungle: New Positions in Black Cultural Studies. New York/London: Routledge (1994), p. 6995.

Metz, Christian. "Identification/Mirror and The Passion for Perceiving," in Gerald Mast, Marshall Cohen and Leo Braudy (editors), Film Theory and Criticism. New York: Oxford University Press (1992), p. 730-745.

Murray, Timothy. Like a Film: Ideological Fantasy on Screen, Camera and Canvas. London/New York: Routledge, 1993.

Narayanan, Vasudha. The Way and the Goal: Expressions of Devotion in the Early Sri Vaisnava Tradition. Washington, D.C. : Institute for Vaishnava Studies, 1987.

Rumi (Jalal al-Din Rumi, Maulana). The Essential Rumi. New York: Harper Collins, 1995. 
Sandilya. "One Hundred Aphorisms of Sandilya," in Manmathamnath Paul (editor), Sacred Books of the Hindus, vol. 7, pt. 2. New York: AMS Press (1974).

Shaviro, Steven. The Cinematic Body. Minneapolis: University of Minnesota Press, 1994.

Silverman, Kaja. The Threshold of the Visible World. New York/London: Routledge, 1996.

Sobchack, Vivian. The Address of the Eye: Phenomenology and Film Experience. Princeton: Princeton University Press, 1992.

Solanas, Fernando, and Octavio Getino. "Towards a Third Cinema," in Michael Chanan (editor), Twenty-Five Years of New Latin American Cinema. London: British Film Institute (1983).

Studlar, Gaylyn. In the Realm of Pleasure: Von Sternburg, Dietrich, and the Masochistic Aesthetic. Chicago/Urbana: University of Illinois Press, 1988.

Waugh, Thomas. Hard to Imagine: A History of Gay Erotica From Its Origins to Stonewall. New York: Columbia University Press, 1996.

Waugh, Thomas. "The Archaeology of Censorship." in Lorraine Johnson (editor), Suggestive Poses: Artists and Critics Respond to Censorship. Toronto: Toronto Photographer's Workshop and Riverbank Press (1997), p. 101-117.

\section{FILM/VIDEOGRAPHY}

De Profundis (1996) by Lawrence Brose. Alternative Images, POB 819, Buffalo, NY 14205.716-849-2792. cepa@aol.com

Frank's Cock (1994) by Mike Hoolboom. Canadian Filmmakers' Distribution Centre, 37 Hanna St., ste. 220, Toronto, ON M6K 1W8. 416-588-0725. fax 416-588-7956. http ://www.cfmdc.org/

Letters from Home (1996) by Mike Hoolboom. Canadian Filmmakers' Distribution Centre.

Nitrate Kisses (1992) by Barbara Hammer. Frameline, 346 Ninth St., San Francisco, CA 94103. 415-703-8654. fax 415-861-1404. frameline@aol.com

Sniff (1997) by Ming-Yuen S. Ma. 1415 Murray Dr., Los Angeles, CA 90026.

The Hundred Videos (1992-96) and Everybody Loves Nothing (1997) by Steve Reinke. V Tape, 401 Richmond St. W, Toronto, ON M5V 3A8. 416-351-1317. fax 416-3511509. video@astral.magic.ca

XCXHXEXRXRXIXEXSX (1980; a performance) by Ken Jacobs. Ken Jacobs, 94 Chambers St., New York, NY 10007. 212-227-3144. 